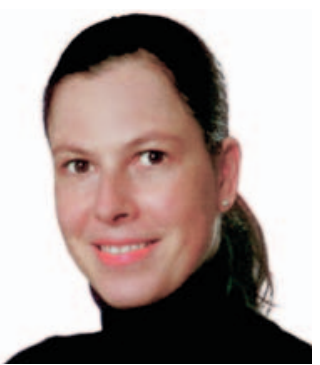

Nicole Stübiger

Universitätsklinikum Hamburg-Eppendorf, Klinik und Poliklinik für Augenheilkunde, Hamburg

\title{
Intraokularen Entzündungen - Schnittstelle Rheumatologie
}

\author{
Ausgewählt und kommentiert von \\ Prof. Dr. Nicole Stübiger (Hamburg)
}

Bei der Uveitis handelt es sich um eine seltene Erkrankung. Die Inzidenz aller Uveitiden beträgt ca. 50/100 000 Einwohner/Jahr. Hierbei handelt es sich in 45\%-60\% der Fälle um eine anteriore Uveitis, in 18\%-23\% um eine Uveitis intermedia, in 7\%-13\% um eine Uveitis posterior und in 5\%-7\% um eine Panuveitis $[1,2]$.

Rund 35\%-50\% der Uveitiden sind mit einer systemischen Grunderkrankung assoziiert hiervon sind je ca. 50\% infektiösen bzw. nicht infektiösen Ursprungs [2-5]. Während bei den infektiösen Ursachen sehr häufig die Toxoplasmose und die Viren der Herpesgruppe zugrunde liegen, ist die Differentialdiagnose (DD) der nicht infektiösen systemischen Erkrankungen sehr mannigfaltig. In Betracht kommen vor allem Erkrankungen aus dem rheumatischen Formenkreis sowie systemische Vaskulitiden und Kollagenosen [1-6].

Häufig werden bei der interdisziplinären Abklärung leider alle Uveitis-Formen «in einen Topf geworfen» und die Patienten dann auf das Vorliegen von «Rheuma» untersucht ohne zu berücksichtigen, dass bereits die Art der okulären Manifestation sowie die Form der Uveitis wichtige differentialdiagnostische Hinweise für eine erfolgreiche Abklärung liefern können und die umgangssprachlich als «Rheuma» bezeichnete rheumatoide Arthritis (RA) zwar die häufigste rheumatische Erkrankung ist (Prävalenz 800-1000/100 000), jedoch nur in Einzelfällen eine intraokulare Manifestation aufweist [3]. Am häufigsten findet sich bei RA-Patienten übrigens eine Keratokonjunktivits sicca (15\%-28\%), seltener eine Episkleritis (0,7\%) oder eine Skleritis (bis zu 6\%). Aufgrund der hohen Prävalenz der RA ist sie jedoch für 10\%-20\% aller Skleritiden verantwortlich und stellt damit die häufigste Ursache für eine Skleritis dar [3].

Die beiden häufigsten Ursachen einer intraokularen Entzündung sind die Sarkoidose $(17,4 \%)$ und die Spondylarthritis (15,8\%) [1-3]. Bei weiterer Differenzierung findet sich als häufigste Genese einer anterioren Uveitis mit 15\%-50\% die HLA B27-assoziierten Erkrankungen (v.a. Spondylarthritis, Psoriasis-Arthritis) bzw. bei Kindern die juvenile idiopathische Arthritis (JIA). Die intermediäre Uveitis ist die Form, die am seltensten mit einer Systemerkrankung vergesellschaftet ist - ca. 55\% der Fälle sind idiopathisch. Wenn doch eine Systemerkrankung zugrunde liegt, dann handelt es sich in ca. 10\% der Fälle um die Multiple Sklerose oder die Sarkoidose. Bei den posterioren Uveitiden bzw. auch bei der Panuveitis muss vor allem an systemische Vaskulitiden gedacht werden. So hatten z.B. in einem großen Uveitisklientel 13\% der Patienten einen Morbus Behçet, aber auch eine Sarkoidose fand sich bei ca. 10\% der Patienten [1-3].

\section{KARGER}

Fax +497614520714 information@karger.com www.karger.com (c) 2017 S. Karger GmbH, Freiburg
Prof. Dr. Nicole Stübiger

Universitätsklinikum Hamburg Eppendor

Klinik und Poliklinik für Augenheilkunde

Martinistraße 52, Gebäude W40, 20246 Hamburg, Deutschland

n.stuebiger@uke.de 
Abschließend ist sicherlich der «Sonderfall Sakoidose» hervorzuheben. Nicht nur, dass die Sarkoidose, als eine der häufigsten systemischen Autoimmunerkrankungen (Prävalenz 46/100 000) - und nicht die RA - die häufigste Ursache für eine Uveitis darstellt, sondern auch, dass sie in die DD jeglicher Uveitis-Form einbezogen werden muss $[3,6,7]$.

\section{Literatur}

1 Barisani-Asenbauer T, Maca SM, Mejdoubi L et al.: Uveitis - a rare disease often associated with systemic diseases and infections - a systemic review of 2619 patients. Orphanet J Rare Dis 2012;7:57-63.

2 Jakob E, Reuland MS, Mackensen F, et al.: Uveitis subtypes in a German interdisclipinary center - analysis of 1916 patients. J Rheumatol 2009;36:127-136.
3 Kötter I, Stübiger N, Deuter C: Augenbeteiligung bei rheumatoider Arthritis, Kollagenosen und Vaskulitiden. Z Rheumatol 2017;76: 673-681.

4 Lee JH, Choi M, Rim THT, et al.: Clinical characteristics and prognostic factors in ankylosing spondylitis associated uveitis. Ocul Immunol Inflamm 2017;DOI:10.1080/09273948.2017.13 59630.
5 Lee JH, Mi H, Lim R, et al.: Ocular autoimmune systemic inflammatory infectious study - report 3: posterior and panuveitis. Ocul Immunol Inflamm 2017;DOI:10.1080/09273948. 2017.1358377

6 Tugal-Tutkun I: Systemic vasculitis and the eye. Curr Opin Rheumatol. 2017;29:24-32.

7 Yang SJ, Salek S, Rosenbaum JT: Ocular sarcoidosis: new diagnostic modalities and treatment. Curr Opin Pulm Med 2017;23(5):458-467.
Lee JH, Choi M, Rim THT, Lee SC, Lee CS: Clinical characteristics and prognostic factors in ankylosing spondylitis associated uveitis. Ocul Immunol Inflamm 2017; DOI:10.1080/09273948.2017.1359630.

Purpose: To identify the clinical features and prognostic factors of uveitis associated with ankylosing spondylitis (AS).

Methods: This retrospective, interventional case series study reviewed the medical records of 91 AS patients with uveitis.

Results: The characteristics of AS-associated uveitis included male preponderance (70\%), average onset in the fourth decade, unilateral manifestation (87.9\%), and vitreous involvement or retinal vascular leakage (36.3\%). All patients had acute anterior uveitis. The best corrected visual acuity in logMAR improved from $0.8 \pm 0.3$ to $0.1 \pm 0.2$. The use of biologic agents was the only significant factor in the multivariate analysis. Patients with vitreous involvement/retinal vascular leakage were more likely to use systemic/ peribulbar steroids for inflammation control, and achieved equally favorable visual outcome as in those without vitreous involvement/retinal vascular leakage.

Conclusion: The clinical characteristics and profile of visual prognostic factors suggest an association between the severity of ocular inflammation and systemic disease.

Kötter I, Stübiger N, Deuter C: Augenbeteiligung bei rheumatoider Arthritis, Kollagenosen und Vaskulitiden. Z Rheumatol 2017;76:673-681.

Zwischen Ophthalmologen und Rheumatologen gibt es diverse Berührungspunkte. Auf der einen Seite steht der Ophthalmologe bei entzündlichen Veränderungen des Auges vor der Frage, ob eine entzündlich rheumatische Systemerkrankung ursächlich ist, umgekehrt muss der Rheumatologe daran denken, dass bei einigen entzündlich rheumatischen Systemerkrankungen häufiger Manifestationen am Auge vorliegen oder dass diese, wenn sie vorhanden sind, die Prognose und damit auch die Therapie maßgeblich beeinflussen. Im Folgenden soll dargestellt werden, welche okulären Entzündungen mit der rheumatoiden Arthritis, Kollagenosen und Vaskulitiden assoziiert sind. Hierbei wird auf die Darstellung der akuten anterioren Uveitiden bei Spondyloarthritiden und derjenigen bei der juvenilen idiopathischen Arthritis verzichtet. Über diese wird an anderer Stelle dieses Heftes berichtet.

\section{Yang SJ, Salek S, Rosenbaum JT: Ocular sarcoidosis: new} diagnostic modalities and treatment. Curr Opin Pulm Med 2017;23:458-467.

Purpose of review: Ocular involvement in sarcoidosis is present in up to $80 \%$ of patients and is frequently manifested before diagnosis of the underlying systemic disease. Considering the therapeutic consequences, early diagnosis of the underlying disease is advantageous in patients presenting with ocular inflammation. There are several ocular findings suggestive of underlying sarcoidosis, such as granulomatous keratic precipitates, iris nodules, cells in the vitreous humor known as snowballs and snowbanks, and retinal periphlebitis. High suspicion is crucial for the diagnosis of sarcoidosis. This review on ocular sarcoidosis will mainly focus on new diagnostic and treatment modalities.

Recent findings: Recent studies found possible new diagnostic indicators for the diagnosis of ocular sarcoidosis which include not only serum profiles but also vitreous sample analysis. Ophthalmologic imaging techniques have improved to investigate the ocular structure in detail. Results from recent uveitis clinical trials have included sarcoidosis as anderlying cause and have reported positive results.

Summary: The diagnosis of ocular sarcoidosis can be challenging in some cases. High suspicion is important to diagnose ocular sarcoidosis with various laboratory and ophthalmic tools. There are many possible options for the treatment of ocular sarcoidosis including various biologic agents. 